\title{
Apakah Status Akreditasi Rumah Sakit Memberikan Perbedaan Pemberian Obat yang Benar dan Keselamatan Pasien?
}

\section{Does Hospital Accreditation Status Differentiate Right Medication Procedure, and Perceived Patient?}

\author{
Saptono Putro ${ }^{1}$, Viera Wardhani ${ }^{2}$, Siswanto ${ }^{2}$ \\ ${ }^{1}$ Rumah Sakit TNI AL Dr. Ramelan Surabaya \\ ${ }^{2}$ Program Studi Magister Manajemen Rumah Sakit, Fakultas Kedokteran Universitas \\ Brawijaya Malang \\ (saptonoputro@gmail.com)
}

\begin{abstract}
ABSTRAK
Akreditasi rumah sakit memberikan panduan implementasi standar manajemen mutu termasuk manajemen pengelolaan obat untuk mengurangi Insiden Keselamatan Pasien (IKP). Penelitian ini bertujuan mengetahui perbedaan implementasi benar pemberian obat dan persepsi IKP berdasarkan status akreditasi rumah sakit. Penelitian ini menggunakan metode survei dengan pendekatan analitik cross sectional, yang membandingkan implementasi benar obat dan persepsi IKP pada 2 rumah sakit tipe D yang berbeda status akreditasinya di wilayah Malang Raya. Pengukuran implementasi benar pemberian obat dan persepsi IKP dilakukan menggunakan kuesioner tertutup pada 36 perawat dan 99 pasien rumah sakit perdana serta 41 perawat dan 96 pasien rumah sakit paripurna. Analisis dilakukan dengan uji Mann Whitney $Z$ test dan uji Rank Spearman test. Kedua rumah sakit menunjukkan tingkat implementasi benar pemberian obat yang baik dan persepsi IKP yang rendah meskipun rumah sakit terakreditasi perdana menunjukkan gambaran yang sedikit lebih baik dibandingkan rumah sakit terakreditasi paripurna. Pada rumah sakit dengan akreditasi perdana menunjukkan bahwa semakin baik implementasi benar pemberian obat maka semakin rendah persepsi IKP menurut perawat maupun pasien. Tidak didapatkan hubungan serupa pada rumah sakit dengan status akreditasi paripurna, tidak ada perbedaan tingkat implementasi benar pemberian obat dan persepsi IKP menurut perawat maupun pasien.
\end{abstract}

Kata kunci : Akreditasi, ketepatan pemberian obat, keselamatan pasien

ABSTRACT

Hospital accreditation provides guidelines for implementing quality management standards including drug management management to reduce the incidence of patient safety (IPS). This study aims to determine the difference between the right implementation of drug administration and the perceieved of IPS based on hospital accreditation status. This researchusing a survey method with cross sectional analytical approach, which compares the correct implementation of the drug and IKP perception in 2 type D hospitals with different accreditation status in the Greater Malang area. Measurements of the correct implementation of drug administration and IKP perceptions were carried out using a closed questionnaire on 36 nurses and 99 primary hospital patients and 41 nurses and 96 full hospital patients. Analysis was carried out by Mann Whitney $Z$ test and Rank Spearman test. Both hospitals showed the correct level of implementation of good drug delivery and low IPS perception even though the first accredited hospital showed a better picture than plenary accredited hospitals. In hospitals with initial accreditation shows that the better the right implementation of drug administration, the lower the perception of IPS according to nurses and patients. There was no similar relationship in the hospital with full accreditation status, where there was no difference in the level of true implementation of drug administration and IKP perception according to nurses and patients.

Keywords : Accreditation, right medication procedure, patient safety 


\section{PENDAHULUAN}

Medication error menempati kelompok urutan pertama insiden keselamatan pasien, dalam proses pelayanan farmasi. ${ }^{1}$ Laporan Peta Nasional Insiden Keselamatan Pasien menunjukkan bahwa medication error merupakan kejadian yang paling sering terjadi $(24,8 \%)$ dari 10 besar IKP yang dilaporkan. ${ }^{1}$ Penelitian yang pernah dilakukan menunjukkan bahwa medication error terjadi pada proses peresepan (5\%-19\%), dispensing oleh farmasi $(2,1 \%-11 \%)$, pemberian obat kepada pasien (5\%-19\%). Angka tersebut lebih tinggi dari standar Departemen Kesehatan untuk kejadian kesalahan pemberian obat yaitu $0 \%{ }^{2}$

Angka medication error yang sangat bervariasi didapatkan juga di negara lain. Sebanyak 45 penelitian yang dilakukan di negara Timur Tengah menemukan variasi angka kesalahan prescribing (peresepan) sebesar 7,1\% sampai 90,5\%, kesalahan administrasi sebesar 9,4\% sampai $80 \%$. Kesalahan paling sering pada peresepan adalah dosis obat yang tidak tepat $(0,15 \%-34,8 \%)$, frekuensi pemberian obat yang tidak tepat. ${ }^{3}$ Penelitian lain yang dilakukan oleh Dedefo di Ethiopia mendapatkan medication error 175 dari 225 kasus $(75,1 \%)$ terdiri dari salah dosis $(23,0 \%)$, diikuti oleh salah obat $(21,2 \%)$ dan salah jadwal $(15,4 \%){ }^{4}$

Kejadian medication error merupakan kejadian yang bisa dicegah, salah satunya dengan penerapan standar Manajemen dan Penggunaan Obat (MPO) yang baik..$^{5}$ Akreditasi rumah sakit di Indonesia versi KARS 2012 menghendaki adanya penerapan standar MPO yang bertujuan untuk keselamatan pasien. Salah satu bagian dari MPO adalah implementasi benar pemberian obat yang merupakan komponen penting dalam pengobatan paliatif, simptomatik, preventif dan kuratif terhadap penyakit dan berbagai kondisi. Komponen MPO mencakup sistem dan proses yang digunakan rumah sakit dalam memberikan farmakoterapi kepada pasien. Hal tersebut merupakan upaya multidisiplin dan terkoordinir dari para staf rumah sakit dalam menerapkan prinsip rancang proses yang efektif, implementasi dan peningkatan seleksi, pengadaan, penyimpanan, pemesanan/peresepan, pencatatan (transcribe), pendistribusian obat, persiapan (preparing), penyaluran (dispensing), pemberian, pendokumentasian dan pemantauan terapi obat. Peran para pemberi pelayanan kese- hatan dalam implementasi benar pemberian obat sangat bervariasi antara satu negara ke negara lain, tetapi proses manajemen obat yang baik bagi keselamatan pasien bersifat universal.

Status akreditasi merupakan pengakuan bahwa rumah sakit sudah memenuhi standar termasuk didalamnya standar MPO pada rumah sakit dengan status akreditasi paripurna. Masih tingginya insiden keselamatan pasien pada beberapa laporan di Indonesia mengindikasikan lemahnya hubungan status akreditasi dan keselamatan pasien. Al Awa menyatakan dalam penelitiannya bahwa 28 dari 81 (34,57\%) indikator keselamatan pasien meningkat secara signifikan selama proses akreditasi di Rumah Sakit King Abdul Aziz University. ${ }^{7}$ Brubakk et al., menyimpulkan bahwa akreditasi dan sertifikasi RS tidak mempunyai kaitan dengan perubahan dalam kualitas pelayanan yang diukur dengan metrik dan standar kualitas. ${ }^{8}$

Review dampak akreditasi menunjukkan masih pentingnya kajian tentang tingkat implementasi standar akreditasi dan pengaruhnya terhadap luaran pelayanan termasuk di dalamnya keselamatan pasien. Disisi lain, kajian di negara berkembang masih terbatas dan belum ada kajian di Indonesia secara spesifik pada aspek manajemen obat. Secara spesifik, implementasi benar pemberian obat diharapkan dapat meningkatkan keselamatan pasien yang merupakan fokus standar akreditasi 2012. Penelitian ini dilakukan untuk melihat sejauh mana status akreditasi mencerminkan implementasi salah satu bagian MPO yaitu benar pemberian obat dan dampaknya pada IKP menurut persepsi perawat dan pasien. Dua rumah sakit dengan akreditasi yang berbeda (Paripurna dan Perdana ) dan dengan tipe rumah sakit D dipilih sebagai subjek kajian.

\section{BAHAN DAN METODE}

Penelitian ini menggunakan metode survei dengan pendekatan analitik cross sectional, yang membandingkan implementasi benar obat dan IKP pada rumah sakit dengan status akreditasi perdana dan paripurna. Seluruh perawat rawat inap sejumlah di 36 perawat RS perdana dan sejumlah 41 perawat RS paripurna. Berdasarkan rumus Lemeshow didapatkan kebutuhan sampel sebesar 96 pasien rawat inap yang diambil secara consecutive hingga jumlah terpenuhi, dengan kriteria usia mi- 
nimal 18 tahun telah menjalani rawat inap minimal 3 hari dan bersedia berpartisipiasi. Pada penelitian ini didapatkan sejumlah responden 99 pasien di RS perdana dan 96 pasiendi RS paripurna. Pasien yang dapat menjadi responden adalah pasien dewasa yang berusia lebih dari 18 tahun, telah menjalani rawat inap lebih dari 2 hari, bisa berkomunikasi dengan lancar, dan setuju untuk menjadi sampel dalam penelitian ini.

Variabel bebas (independent) pada penelitian ini yaitu status akreditasi rumah sakit. Variabel luaran yang diukur adalah implementasi benar pemberian obat dan IKP menurut persepsi perawat dan pasien. Implementasi benar pemberian obat menurut perawat diukur dengan 12 item pertanyaan, serta oleh pasien dengan 8 item pertanyaan. Persepsi IKP menurut perawat diukur dengan 7 item pertanyaan meliputi 4 item tentang Kejadian Tidak Cedera (KTC), 1 Kejadian Nyaris Cedera (KNC) dan 2 Kejadian Tidak Diharapkan (KTD) sedangkan persepsi pasien terdiri 9 item pertanyaan yang meliputi $5 \mathrm{KTC}$ dan 2 KTD. Semua kuesioner diukur dengan menggunakan skala Likert dengan rating scale 1-4: tidak per-

Tabel 1a. Perbedaan Frekuensi Implementasi Benar Pemberian Obat Menurut Persepsi Perawat dan Pasien

\begin{tabular}{|c|c|c|c|c|c|c|c|c|}
\hline \multirow[b]{2}{*}{$\begin{array}{c}\text { Item Benar } \\
\text { Pemberian Obat }\end{array}$} & \multicolumn{4}{|c|}{ RS Perdana } & \multicolumn{4}{|c|}{ RS Paripurna } \\
\hline & $\begin{array}{c}\text { Tidak } \\
\text { Pernah } \\
\text { n (\%) } \\
\end{array}$ & $\begin{array}{l}\text { Kadang } \\
\text { n (\%) }\end{array}$ & $\begin{array}{l}\text { Sering } \\
\text { n (\%) }\end{array}$ & $\begin{array}{l}\text { Selalu } \\
\text { n (\%) }\end{array}$ & $\begin{array}{c}\text { Tidak } \\
\text { Pernah } \\
\text { n (\%) } \\
\end{array}$ & $\begin{array}{c}\text { Kadang } \\
\text { n (\%) }\end{array}$ & $\begin{array}{l}\text { Sering } \\
\text { n (\%) }\end{array}$ & $\begin{array}{l}\text { Selalu } \\
\text { n (\%) }\end{array}$ \\
\hline $\begin{array}{l}\text { Persepsi Perawat } \\
\text { Item } 1 \\
\text { (benar identitas) }\end{array}$ & $0(0.0)$ & $1(2.8)$ & $2(5.6)$ & $33(91.7)$ & $0(0.0)$ & $1(2.4)$ & $4(9.8)$ & $36(87.8)$ \\
\hline $\begin{array}{l}\text { Item } 2 \\
\text { (benar identitas) }\end{array}$ & $0(0.0)$ & $0(0.0)$ & $4(11.1)$ & $32(88.9)$ & $0(0.0)$ & $0(0.0)$ & $5(12.2)$ & $36(87.8)$ \\
\hline $\begin{array}{l}\text { Item } 3 \\
\text { (benar obat) }\end{array}$ & $0(0.0)$ & $1(2.8)$ & $2(5.6)$ & $33(91.7)$ & $0(0.0)$ & $1(2.4)$ & $8(19.5)$ & $32(78.0)$ \\
\hline $\begin{array}{l}\text { Item } 4 \\
\text { (benar obat) }\end{array}$ & $0(0.0)$ & $1(2.8)$ & $2(5.6)$ & $33(91.7)$ & $0(0.0)$ & $0(0.0)$ & $7(17.1)$ & $34(82.9)$ \\
\hline $\begin{array}{l}\text { Item } 5 \\
\text { (benar obat) }\end{array}$ & $0(0.0)$ & $1(2.8)$ & $2(5.6)$ & $33(91.7)$ & $2(4.9)$ & $6(14.6)$ & $18(43.9)$ & $15(36.6)$ \\
\hline $\begin{array}{l}\text { Item } 8 \\
\text { (benar jadwal) }\end{array}$ & $0(0.0)$ & $0(0.0)$ & $2(5.6)$ & $34(94.4)$ & $0(0.0)$ & $0(0.0)$ & $6(14.6)$ & $35(85.4)$ \\
\hline $\begin{array}{l}\text { Item } 9 \\
\text { (benar jadwal) }\end{array}$ & $0(0.0)$ & $1(2.8)$ & $3(8.3)$ & $32(88.9)$ & $0(0.0)$ & $0(0.0)$ & $5(12.2)$ & $36(87.8)$ \\
\hline $\begin{array}{l}\text { Item } 10 \\
\text { (benar informasi) }\end{array}$ & $0(0.0)$ & $0(0.0)$ & $4(11.1)$ & $32(88.9)$ & $0(0.0)$ & $0(0.0)$ & $10(24.4)$ & $31(75.6)$ \\
\hline $\begin{array}{l}\text { Item } 11 \\
\text { (benar informasi) }\end{array}$ & $1(2.8)$ & $3(8.3)$ & $7(19.4)$ & $25(69.4)$ & $0(0.0)$ & $3(7.3)$ & $14(34.1)$ & $24(58.5)$ \\
\hline $\begin{array}{l}\text { Item } 13 \\
\text { (benar informasi) }\end{array}$ & $0(0.0)$ & $0(0.0)$ & $9(25.0)$ & $27(75.0)$ & $0(0.0)$ & $2(4.9)$ & $11(26.8)$ & $28(68.3)$ \\
\hline $\begin{array}{l}\text { Item } 14 \\
\text { (benar amdinistrasi) }\end{array}$ & $0(0.0)$ & $3(8.3)$ & $5(13.9)$ & $28(77.8)$ & $0(0.0)$ & $1(2.4)$ & $11(26.8)$ & $29(70.7)$ \\
\hline $\begin{array}{l}\text { Item } 15 \\
\text { (benar administrasi) }\end{array}$ & $3(8.3)$ & $7(19.4)$ & $5(13.9)$ & $21(58.3)$ & $0(0.0)$ & $1(2.4)$ & $13(31.7)$ & $27(65.9)$ \\
\hline
\end{tabular}


Tabel 1b. Perbedaan Frekuensi Implementasi Benar Pemberian Obat Menurut Persepsi Perawat dan Pasien

\begin{tabular}{|c|c|c|c|c|c|c|c|c|}
\hline \multirow[b]{2}{*}{$\begin{array}{c}\text { Item Benar } \\
\text { Pemberian Obat }\end{array}$} & \multicolumn{4}{|c|}{ RS Perdana } & \multicolumn{4}{|c|}{ RS Paripurna } \\
\hline & $\begin{array}{l}\text { Tidak } \\
\text { Pernah } \\
\text { n (\%) }\end{array}$ & $\begin{array}{c}\text { Kadang } \\
\text { n (\%) }\end{array}$ & $\begin{array}{l}\text { Sering } \\
\text { n (\%) }\end{array}$ & $\begin{array}{l}\text { Selalu } \\
\text { n (\%) }\end{array}$ & $\begin{array}{l}\text { Tidak } \\
\text { Pernah } \\
\text { n (\%) }\end{array}$ & $\begin{array}{c}\text { Kadang } \\
\text { n (\%) }\end{array}$ & $\begin{array}{l}\text { Sering } \\
\text { n (\%) }\end{array}$ & $\begin{array}{l}\text { Selalu } \\
\text { n (\%) }\end{array}$ \\
\hline $\begin{array}{l}\text { Persepsi Pasien } \\
\text { Item 1 (benar } \\
\text { identitas) }\end{array}$ & $5(5.1)$ & $8(8.1)$ & $9(9.1)$ & $77(77.8)$ & $4(4.2)$ & $10(10.4)$ & $14(14.6)$ & $68(70.8)$ \\
\hline $\begin{array}{l}\text { Item } 3 \text { (benar } \\
\text { informasi/obat) }\end{array}$ & $4(4.0)$ & $2(2.0)$ & $9(9.1)$ & $84(84.8)$ & $17(17.7)$ & $10(10.4)$ & $15(15.6)$ & $54(56.3)$ \\
\hline $\begin{array}{l}\text { Item } 4 \text { (benar } \\
\text { informasi/dosis) }\end{array}$ & $8(8.1)$ & $11(11.1)$ & $7(7.1)$ & $73(73.7)$ & $23(24.0)$ & $9(9.4)$ & $16(16.7)$ & $48(50.0)$ \\
\hline $\begin{array}{l}\text { Item } 5 \text { (benar } \\
\text { informasi/dosis) }\end{array}$ & $4(4.0)$ & $2(2.0)$ & $6(6.1)$ & 87 (87.9) & $5(5.2)$ & $9(9.4)$ & $15(15.6)$ & $67(69.8)$ \\
\hline $\begin{array}{l}\text { Item } 6 \text { (benar } \\
\text { jadwal) }\end{array}$ & $2(2.0)$ & $2(2.0)$ & $10(10.1)$ & $85(85.9)$ & $3(3.1)$ & $4(4.2)$ & $11(11.5)$ & $78(81.3)$ \\
\hline $\begin{array}{l}\text { Item } 7 \text { (benar } \\
\text { jadwal) }\end{array}$ & $3(3.0)$ & $1(1.0)$ & $8(8.1)$ & 87 (87.9) & $1(1.0)$ & $3(3.1)$ & $20(20.8)$ & $72(75.0)$ \\
\hline $\begin{array}{l}\text { Item } 8 \text { (benar } \\
\text { jadwal) }\end{array}$ & $2(2.0)$ & $2(2.0)$ & $5(5.1)$ & $90(90.9)$ & $8(8.3)$ & $10(10.4)$ & $15(15.6)$ & $63(65.6)$ \\
\hline $\begin{array}{l}\text { Item } 9 \text { (benar } \\
\text { informasi) }\end{array}$ & $11(11.1)$ & $6(6.1)$ & $9(9.1)$ & $73(73.7)$ & $25(26.0)$ & $25(26.0)$ & $10(10.4)$ & $36(37.5)$ \\
\hline
\end{tabular}

nah, kadang-kadang, sering, selalu. Nilai jawaban dijumlah kemudian direrata. Item kuesioner telah diuji validitas dan reliabilitasnya. Analisis Mann-Whitney digunakan untuk mengetahui perbedaan implementasi benar pembeian obat dan insiden keselamatan pasien menurut status akreditasi rumah sakit. Untuk mengetahui korelasi antara implementasi benar pemberian obat dengan persepsi IKP digunakan uji rank Spearman.

\section{HASIL}

Secara deskriptif sebagian besar responden baik perawat maupun pasien menyatakan bahwa implementasi benar pemberian obat menurut perawat secara umum sudah selalu dilaksanakan pada kedua rumah sakit. Meskipun hanya sebagian kecil masih didapatkan responden yang menyebutkan implementasi yang hanya dilakukan"kadang-kadang" (5,055\%) bahkan "tidak pernah" (4,37\%). Sebagian kecil perawat $(4,37 \%$ $5,66 \%)$ tidak selalu melakukan implementasi be- nar identitas (1 item), benar obat (3 item) benar jadwal (1 item), benar informasi (2 item), dan benar administrasi (1 item) masih kadang-kadang dilakukan (Tabel 1).

Implementasi yang "tidak pernah" dilakukan masih didapatkan pada benar informasi (item 11) sebesar $2,8 \%$ dan benar administrasi (item 15) sebesar 8,3\% pada RS perdana. Di RS paripurna juga ditemukan item yang "tidak pernah" dilakukan pada implementasi benar obat (item 5) sebesar 4,9\%. Disisi lain, menurut pasien masih ditemukan adanya prosedur benar pemberian obat yang hanya dilakukan "kadang-kadang" (4,28\%-10,4\%), bahkan "tidak pernah" $(4,91 \%-11,1 \%)$ oleh perawat. Data tersebut ditemukan pada kedua rumah sakit. Aspek benar pemberian obat yang masih "tidak pernah" dilakukan oleh sebagian kecil perawat ditemukan pada RS perdana maupun RS paripurna adalah benar identitas (item 1), benar obat (item 3), benar dosis (item 4, 5), benar jadwal (item 6,7, 8) dan benar informasi (item 9) (Tabel 1). 
Tabel 2. Nilai Implementasi Benar Pemberian Obat, Rerata Persepsi Kejadian Potensi Cidera, Kejadian Tidak Cidera, Kejadian Tidak Diharapkan pada Rumah Sakit Menurut Perawat dan Pasien

\begin{tabular}{lcccc}
\hline \multirow{2}{*}{ Item } & \multicolumn{2}{c}{ RS Perdana } & \multicolumn{2}{c}{ RS Paripurna } \\
\cline { 2 - 5 } & Perawat & Pasien & Perawat & Pasien \\
\hline Rerata Implementasi benar pemberian obat & 3,78 & 3,68 & 3,69 & 3,30 \\
Benar 1 (identitas) & 3,89 & 3,60 & 3,86 & 3,52 \\
Benar 2 (obat) & 3,89 & 3,75 & 3,51 & 3,10 \\
Benar 3 (jadwal) & 3,95 & 3,82 & 3,85 & 3,01 \\
Benar 4 (informasi) & 3,73 & 3,56 & 3,61 & 3,60 \\
Benar 5 (administrasi) & 3,44 & - & 3,65 & - \\
Nilai rerata IKP & 1,10 & 1,09 & 1,16 & 1,08 \\
KPC & 1,14 & 1,08 & 1,29 & 1,01 \\
Salah obat & 1,14 & 1,08 & 1,29 & 1,01 \\
Rerata KTD & 1,19 & 1,12 & 1,38 & 1,13 \\
Salah dosis & 1,06 & - & 1,12 & - \\
Salah obat & 1,33 & 1,12 & 1,63 & 1,13 \\
Rerata KTC & 1,05 & 1,09 & 1,03 & 1,07 \\
Salah obat & 1,06 & 1,12 & 1,03 & 1,12 \\
Salah identitas & 1,03 & 1,11 & 1,00 & 1,06 \\
Salah dosis & 1,06 & 1,06 & 1,05 & 1,05 \\
\hline
\end{tabular}

Tabel 3. Hubungan Status Akreditasi dengan Implementasi Benar Pemberian Obat

\begin{tabular}{|c|c|c|c|c|c|}
\hline \multirow{2}{*}{ Persepsi } & \multicolumn{2}{|c|}{ Status Akreditasi } & \multirow{2}{*}{\multicolumn{3}{|c|}{ Hasil uji Mann Whitney Z-test }} \\
\hline & Perdana & Paripurna & & & \\
\hline \multicolumn{6}{|l|}{$\begin{array}{l}\text { Implentasi benar } \\
\text { pemberian obat }\end{array}$} \\
\hline Perawat & 3.780 & 3.699 & $Z=-1.992$ & $\mathrm{p}=0.046<$ alpha 0.05 & Signifikan \\
\hline Pasien & 3.687 & 3.305 & $Z=-4.791$ & $\mathrm{p}=0.000<$ alpha 0.05 & Signifikan \\
\hline \multicolumn{6}{|c|}{$\begin{array}{l}\text { Insiden keselamatan } \\
\text { pasien }\end{array}$} \\
\hline Perawat & 1.099 & 1.164 & $Z=-3.234$ & $\mathrm{p}=0.001<$ alpha 0.05 & Signifikan \\
\hline Pasien & 1.098 & 1.082 & $Z=-1.798$ & $p=0.072>$ alpha 0.05 & Tidak signifikan \\
\hline
\end{tabular}

Kedua rumah sakit, secara deskriptif menunjukkan tingkat implementasi benar pemberian obat dan persepsi insiden yang sama, walaupun terdapat nilai perbedaan yang kecil, Rumah sakit dengan status akreditasi Perdana cenderung menunjukkan gambaran yang lebih baik. Jumlah respon yang menyatakan ada aspek prosedur benar pemberian obat yang "tidak pernah" dilakukan walau hanya sedikit, lebih banyak dinyatakan pada rumah sakit yang terakreditasi paripurna dibandingkan terakreditasi perdana. Rerata implementasi benar pemberian obat menurut perawat maupun pasien di RS perdana didapatkan lebih tinggi dibandingkan dengan perawat dan pasien di RS paripurna (Tabel 2). Demikian juga rerata persepsi insiden keselamatan pasien menurut perawat di RS per- dana lebih rendah dibandingkan dengan perawat di RS paripurna $(1,10$ dibandingkan 1,16$)$. Nilai rerata menurut pasien relatif sama pada kedua rumah sakit (1,09 dibandingkan 1,08) (Tabel 2).

Hasil menunjukkan terdapat perbedaan implementasi benar pemberian obat menurut perawat maupun pasien yang signifikan secara statistik, meskipun secara umum pada kedua rumah sakit tersebut telah menunjukkan tingkat implementasi "hampir selalu" hingga "selalu", dengan tingkat implementasi pada RS perdana yang sedikit lebih tinggi dari RS paripurna. Persepsi pasien tentang tingkat insiden keselamatan pasien pada rumah sakit dengan status akreditasi menunjukkan perbedaan yang menunjukkan selisih intensitas antara "tidak pernah" hingga "kadang terjadi". Per- 
Tabel 4. Hubungan Status Akreditasi dengan Implementasi Benar Pemberian Obat

\begin{tabular}{|c|c|c|c|}
\hline \multirow{2}{*}{ Status Akreditasi RS } & \multicolumn{2}{|c|}{ Hasil uji Spearman test } & \multirow{2}{*}{ Keterangan } \\
\hline & Koefisien & Probabilitas & \\
\hline \multicolumn{4}{|l|}{ Perdana } \\
\hline Perawat & -0.418 & 0.011 & $\mathrm{p}<$ alpha 0.05 Signifikan \\
\hline Pasien & -0.384 & 0.000 & $\mathrm{p}<$ alpha 0.05 Signifikan \\
\hline \multicolumn{4}{|l|}{ Paripurna } \\
\hline Perawat & -0.011 & 0.946 & $\mathrm{p}>$ alpha 0.05 Tidak Signifikan \\
\hline Pasien & -0.126 & 0.222 & $\mathrm{p}>$ alpha 0.05 Tidak Signifikan \\
\hline
\end{tabular}

bedaan ini tidak ditemukan bila menurut perawat (Tabel 3). Secara operasional angka perbedaan yang ditemukan baik tentang implementasi benar obat maupun persepsi intensitas insiden menurut perawat maupun pasien hanya minimal $(<1)$, tetapi selisih tersebut menggambarkan rentang diantara dua skala, yang mengindikasikan potensi perbedaan bila digunakan skala yang lebih kecil ( $>4$ skala). Meskipun secara deskriptif kecil, hal ini tetap penting disajikan karena kondisi keselamatan pasien yang diharapkan adalah bebas dari risiko dan kesalahan.

Berdasarkan spearman test pada rumah sakit yang terakreditasi perdana terdapat hubungan negatif implementasi benar pemberian obat dengan insiden keselamatan pasien menurut perawat maupun pasien. Hubungan negatif tersebut cukup kuat (koefisien : -0.418) menurut perawat, demikian juga menurut pasien didapatkan hubungan negatif bersifat cukup kuat (koefisien : -0.384). Semakin tinggi tingkat implementasi benar pemberian obat, maka semakin rendah persepsi insiden keselamatan pasien. Pada rumah sakit yang terakreditasi paripurna tidak terdapat hubungan antara implementasi benar pemberian obat dengan insiden keselamatan pasien menurut perawat maupun pasien (koefisien : -0.011 dan koefisien : -0,126) (Tabel 4).

\section{PEMBAHASAN}

Penelitian ini mengidentifikasi secara keseluruhan implementasi benar pemberian obat sudah baik. Meskipun demikian, tingkat implementasi benar pemberian obat pada rumah sakit dengan status akreditasi perdana sedikit lebih tinggi apabila dibandingkan rumah sakit dengan status paripurna, baik menurut perawat maupun pasien. Hanya sebagian saja perawat yang belum selalu melakukan implementasi pemberian benar obat.
Meskipun demikian masih terdapat aspek implementasi yang tidak pernah atau hanya kadangkadang diterapkan yaitu sebagian item pada aspek benar informasi dan administrasi. Demikian juga IKP yang dilaporkan menurut persepsi perawat dan pasien pada rumah sakit dengan akreditasi perdana sedikit lebih rendah dibandingkan yang paripurna. Semakin tinggi implementasi benar pemberian obat akan semakin rendah tingkat IKP.

Secara keseluruhan implementasi benar pemberian obat menurut perawat sudah baik dengan nilai rata-rata RS akreditasi Perdana sedikit lebih tinggi daripada RS akreditasi Paripurna (3,780 dibanding 3,699). Angka ini menggambarkan bahwa hampir semua perawat selalu melaksanakan implementasi benar pemberian obat. Namun demikian, masih terdapat beberapa perawat yang menyatakan belum melaksanakan implementasi benar pemberian obat. Aspek benar pemberian obat yang tidak pernah dilakukan oleh sebagian kecil $(5,055 \%)$ perawat RS Perdana yaitu, benar informasi, dan benar administrasi. Pada RS Paripurna terdapat sebagian kecil perawat $(4,9 \%)$ yang tidak pernah melakukan benar obat saat pergantian jaga ruang.

Belum terpenuhinya implementasi benar obat juga ditemukan pada penelitian sebelumnya. Sebuah penelitian menemukan implementasi benar pasien hanya $64,9 \%, 86,5 \%$ benar obat, dan $64,9 \%$ benar waktu jadwal. ${ }^{9}$ Fatimah dalam penelitiannya mendapatkan bahwa sebanyak $>50 \%$ perawat belum melaksanakan benar identitas, $31,2 \%$ belum melaksanakan prinsip benar obat, 3,1\% belum benar jadwal, $53,1 \%$ belum benar informasi, dan $100 \%$ masih salah dalam dokumentasi/ administrasi.$^{10}$ Pranasari dalam penelitian praktek pemberian obat oleh perawat mendapatkan hasil $87,8 \%$ benar pasien, $95,1 \%$ benar dosis, $87,8 \%$ benar obat, $73,2 \%$ benar jadwal, $34,1 \%$ benar do- 
kumentasi. ${ }^{11}$

Kemampuan perawat melakukan implementasi Standar Operasional Prosedur (SOP) implementasi benar obat bisa dipengaruhi oleh beberapa faktor seperti usia, tingkat pendidikan, dan motivasi. ${ }^{12}$ Setiawan dan Budiastuti menjelaskan bahwa usia merupakan salah satu karateristik perawat yang memiliki hubungan stimulan dalam melakukan sebuah pekerjaan dan memiliki pengaruh terhadap diri mereka. ${ }^{13}$ Virawan menyatakan bahwa tidak ada hubungan antara usia dengan kemampuan perawat dalam memberikan obat kepada pasien, akan tetapi tergantung dari pengalaman dan pengetahuan yang diperoleh perawat itu sendiri. ${ }^{14}$ Dalam penelitian ini perawat di RS perdana memiliki karakteristik usia, tingkat pendidikan, lama bekerja lebih rendah bila dibandingkan RS paripurna.

Untuk menghasilkan kinerja perawat yang maksimal, seorang perawat rumah sakit harus memiliki tingkat kemampuan dan pemahaman yang tinggi terhadap pekerjaannya. ${ }^{15} \mathrm{Hal}$ ini akan mempengaruhi hasil tindakan dalam proses administrasi dan pendokumentasian maupun prosedur pemberian obat yang sesuai. Pendokumentasian keperawatan merupakan hal yang penting dikarenakan pendokumentasian merupakan bukti perawat telah melakukan tindakan kepada pasien sesuai standar prosedur. ${ }^{16}$ Pendokumentasian dipengaruhi oleh faktor-faktor tanggung jawab, penilaian perawat, pengakuan perawat, pengawasan, dan dukungan rekan kerja dalam meningkatkan kepatuhan dokumentasi keperawatan. ${ }^{17}$

Belum terpenuhinya implementasi benar pemberian obat juga dapat terjadi karena komunikasi yang tidak baik antara perawat dengan pasien. Komunikasi baik secara verbal dan non verbal sangat dibutuhkan dalam menunjang keberhasilan kesembuhan pasien melalui teknik berkomunikasi yang efektif. Komunikasi perawat memiliki kontribusi yang unik terhadap keluarga dan pasien yang sangat berpengaruh terhadap kepuasan pasien. ${ }^{18}$ Komunikasi yang tidak efektif antara perawat dengan perawat dan juga perawat dengan pasien/keluarga pasien menjadi salah satu faktor yang mempengaruhi penerapan prinsip tujuh benar pada proses pemberian obat.

Tingkat implementasi benar obat yang lebih tinggi di RS dengan status perdana tidak sesuai dengan hipotesis bahwa pelaksanaan akreditasi RS dapat menuntun para pelaksana pelayanan untuk bekerja sesuai standar yang ditetapkan. ${ }^{19}$ Akreditasi rumah sakit seharusnya mempunyai dampak yang positif terhadap kualitas perawatan yang diberikan kepada pasien dan kepuasan pasien. ${ }^{20}$ Penerapan standar akreditasi mendorong perubahan pelayanan oleh rumah sakit yang lebih berkualitas dan peningkatan kerjasama antara disiplin profesi dalam perawatan pasien. ${ }^{21}$

Penerapan sebuah standar memerlukan pengawasan dan evaluasi secara periodik untuk meyakinkan bahwa semua aktivitas benar-benar dikerjakan dengan sepenuh hati dan menjadi sebuah kebiasaan atas dasar kesadaran. Faktor lain yang menjelaskan temuan ini adalah kesiapan rumah sakit menjelang survei akreditasi. Penelitian di kedua RS ini dilakukan pada saat menjelang verifikasi akreditasi. RS perdana akan melakukan verifikasi akreditasi dalam kurun waktu kurang lebih 3 bulan, sedangkan RS Paripurna dalam 6 bulan kemudian.

Secara keseluruhan persepsi IKP menurut perawat sudah baik dengan nilai rata-rata RS akreditasi Perdana lebih rendah daripada RS akreditasi Paripurna (1,099 dibanding 1,164). Angka ini menggambarkan bahwa perawat menyatakan hampir tidak pernah mengalami atau melakukan insiden keselamatan pasien. Namun demikian, masih ada sebagian perawat yang menyatakan melakukan insiden keselamatan pasien.

Insiden keselamatan pasien menurut pasien juga sudah baik dengan nilai rata-rata pada RS akreditasi Perdana 1,098 dan RS akreditasi Paripurna 1,082. Angka ini menggambarkan bahwa menurut pasien, perawat hampir tidak pernah melakukan insiden keselamatan pasien. Masih ada 1 pasien yang menyatakan sebagian kecil perawat yang kadang melakukan tindakan yang termasuk kejadian nyaris cidera dan 1 pasien menyatakan masih ada perawat yang melakukan kejadian tidak diharapkan. Untuk mendukung pelayanan keperawatan yang terstandar, khususnya implementasi benar pemberian obat, fungsi supervisi memegang peranan penting dalam manajemen mutu. Supervisi adalah pengamatan secara langsung dan berkala oleh atasan terhadap pekerjaan yang dilaksanakan oleh bawahan untuk kemudian apabila ditemukan masalah, segera diberikan petunjuk atau bantu- 
an yang bersifat langsung guna mengatasinya. ${ }^{22}$ Melalui supervisi, SDM keperawatan dapat mempertahankan kemampuan dan perilakunya dalam melaksanakan asuhan keperawatan sehingga kualitas asuhan yang diterima oleh pasien selalu sama. Kepala ruangan serta tim mutu harus saling berkoordinasi terhadap fungsi pengawasan atau supervisi demi tercapainya tujuan kegiatan keselamatan pasien. Kepala ruangan dapat mengawasi kinerja perawat ruangannya dan tim mutu dapat mengawasi kinerja kepala ruangan serta melakukan supervisi di ruang rawat inap. Jika tugas pengawasan tersebut dilaksanakan dengan baik, maka dapat mengurangi insiden keselamatan pasien. $^{23}$

Berdasarkan hasil analisis dapat diinformasikan bahwa terdapat perbedaan yang signifikan implementasi benar pemberian obat menurut perawat maupun menurut pasien, antara di rumah sakit terakreditasi Perdana dan terakreditasi Paripurna. Secara statistik, implementasi benar pemberian obat di rumah sakit menurut perawat maupun pasien diketahui bahwa RS dengan akreditasi perdana hanya sedikit lebih baik daripada RS dengan akreditasi paripurna, meskipun kedua rumah sakit sudah masuk dalam kriteria baik.

Keterkaitan status akreditasi dengan insiden keselamatan pasien menurut pasien tidak menunjukkan perbedaan yang signifikan. Nilai rerata persepsi pasien di kedua rumah sakit juga sudah masuk dalam kategori baik. Akreditasi rumah sakit seharusnya mempunyai dampak yang positif terhadap kualitas perawatan yang diberikan kepada pasien dan kepuasan pasien. ${ }^{13}$ Penerapan standar akreditasi mendorong perubahan pelayanan oleh rumah sakit yang lebih berkualitas dan peningkatan kerjasama antara disiplin profesi dalam perawatan pasien. ${ }^{14}$

Departemen Kesehatan RI tahun 2006 menyebutkan bahwa peristiwa yang tidak diinginkan di rumah sakit merupakan kesalahan dalam proses pelayanan yang sebetulnya dapat dicegah melalui rencana pelayanan yang komprehensif dengan melibatkan pasien berdasarkan haknya. Oleh karena itu, program keselamatan pasien ( $p a-$ tient safety), khususnya implementasi benar pemberian obat harus dibudayakan yang tentunya akan mendorong perawat dapat bekerja lebih berkuali- tas sehingga dapat mencegah terjadinya IKP.

Terdapat hubungan yang signifikan antara implementasi benar pemberian obat dengan IKP, baik menurut perawat maupun pasien pada rumah sakit yang terakreditasi Perdana. Disisi lain, pada rumah sakit yang terakreditasi Paripurna menunjukkan bahwa tidak terdapat hubungan yang signifikan antara implementasi benar pemberian obat dengan Insiden Keselamatan Pasien, baik menurut perawat maupun pasien. Temuan ini mengindikasikan bahwa implementasi benar pemberian obat belum mencerminkan status akreditasi yang dimiliki. Rumah sakit yang sudah terakreditasi diharapkan memiliki dampak yang positif pada kualitas perawatan dan kepuasan kepada pasien. ${ }^{13}$ RS yang terakreditasi Paripurna seharusnya sudah lebih matang dan lebih siap serta lebih berpengalaman dalam menjalankan implementasi benar pemberian obat guna memperbaiki catatan angka IKP.

Waktu pelaksanaan penelitian dapat mempunyai pengaruh terhadap hasil penelitian ini. Pada saat penelitian RS Perdana dalam keadaan 2-3 bulan menjelang dilaksanakan verifikasi re-akreditasi oleh KARS. Hal ini menjadikan perawat RS Perdana lebih siap menghadapi verifikasi dibandingkan RS Paripurna yang masih mempunyai waktu 6 bulan menjelang verifikasinya. Keterbatasan dalam penelitian ini penulis belum bisa menggali lebih dalam alasan responden menjawab item pertanyaan dengan jawaban selalu sering, kadangkadang, dan tidak pernah. Jawaban yang diberikan dapat dipengaruhi oleh beban kerja, persepsi, dan ketersediaan waktu dalam menjawab kuesioner. Selain itu, skala yang diukur merupakan persepsi dan belum menggambarkan angka insiden yang sebenarnya, tetapi persepsi dapat mengatasi hambatan pelaporan dan mengindikasikan potensi insiden yang tidak dilaporkan.

\section{KESIMPULAN DAN SARAN}

Pada kedua rumah sakit, implementasi benar pemberian obat sudah baik dan intensitas insiden keselamatan pengobatan juga rendah menurut persepsi perawat dan pasien. Meskipun demikian rumah sakit perdana mempunyai implementasi benar pemberian obat yang sedikit lebih baik dan insiden keselamatan pasien yang lebih rendah baik menurut perawat maupun pasien bila dibandingkan dengan rumah sakit terakreditasi 
paripurna. Pada rumah sakit perdana semakin baik implementasi benar pemberian obat akan semakin rendah insiden keselamatan pasien menurut persepsi perawat dan pasien, tetapi hubungan serupa tidak ditemukan pada rumah sakit paripurna. Implementasi benar pemberian obat berhubungan dengan penuruan insiden keselamatan pasien sehingga rumah sakit dapat meningkatkan implementasi benar pemberian obat, melalui peningkatan supervisi dan monitoring berkelanjutan. Untuk penelitian sejenis selanjutnya penulis menyarankan untuk memasukkan data riil IKP yang terjadi pada rumah sakit untuk bisa dikonfirmasikan dengan pesepsi IKP menurut responden.

\section{DAFTAR PUSTAKA}

1. Depkes, RI. Panduan Nasional Keselamatan Pasien Rumah Sakit. Jakarta : Departemen Kesehatan Republik Indonesia; 2008.

2. Depkes, RI. Standar Pelayanan Minimal Rumah Sakit. Jakarta : Direktorat Jendral Pelayanan Medik. Depkes RI; Cetakan: I. 2007.

3. Alimin, R. S. T. I. S. Faktor Penyebab Medication Error di Instalasi Rawat. Jurnal Manajemen Pelayanan Kesehatan. 2012;15(4): 182-187.

4. Alsulami, Z., Conroy, S. \& Choonara, I. Medication Errors in The Middle East Countries: A Systematic Review of The Literature. European Journal Of Clinical Pharmacology. 2013;69: 995-1008.

5. Dedefo, M. G., Mitike, A. H. \& Angamo, M. T. Incidence and Determinants of Medication Errors and Adverse Drug Events Among Hospitalized Children in West Ethiopia. BMC Pediatrics. 2016;16:81.

6. Putri, H. H. Y. Implementasi Manajemen Keselamatan Pasien (Patient Safety) dalam Usaha Pencegahan Medication Error di RSUD Dr. Moewardi Tahun 2015 [Tesis]. Surakarta: Universitas Muhammadiyah; 2015.

7. Al-Awa, B., De Wever, A., Melot, C. \& Devreux, I. An Overview of Patient Safety and Accreditation: A Literature Review Study. Res J Med Sci. 2011;5:200-23.

8. Brubakk, K., Vist, G. E., Bukholm, G., Barach, P. \& Tjomsland, O. A Systematic Review of Hospital Accreditation: The Challenges of Measuring Complex Intervention
Effects. BMC Health Services Research. 2015;15:280.

9. Bhatti, K.K., Qureshi, T. M., 2007. Impact of Employee Participation on Job Satisfaction, Employee Commitment and Employee Productivity. International Review of Business Research Papers. 2015; 3(2): 54-68.

10. Sthephani P., Dewanto A. and Widijati I.C., Faktor Penghambat Pelaksanaan SPO Benar dalam Pemberian Obat di Ruang Rawat Inap Rumah Sakit Panti Nirmala. Jurnal Kedokteran Brawijaya. 2015; 28(Supp. 2): 228-234.

11. Pranasari, Redha. Gambaran Pemberian Obat dengan Prinsip 7 oleh Perawat di RSU PKU Muhammadiyah Bantul. (Online) 2016. dihttp://repository.umy.ac.id/handle/123456789/2697. [diakses tanggal 18 Mei 2018].

12. Harmiady, R. Faktor- Faktor yang Berhubungan dengan Pelaksanaan Prinsip 6 Benar dalam Pemberian Obat oleh Perawat Pelaksana di Ruang Interna dan Bedah Rumah Sakit Haji Makassar. Jurnal Ilmiah Kesehatan Diagnosis. 2014; -5(4); -2302-1721.

13. Setiawan, A. \& Budiastuti, T. Pengaruh Karakteristik Individu dan Faktor-Faktor Pekerjaan terhadap Motivasi. (Online) 2012. di http:// jurnal.widyamanggala.ac.id/index.php/wm$\mathrm{keb} /$ article/download/61/52. [diakses tanggal20 Mei 2018].

14. Virawan, M.K. Faktor-Faktor yang Mempengaruhi Kepatuhan Staff Perawat dan Staf Farmasi Menggunakan Enam Benar dalam Menurunkan Kasus Kejadian yang Tidak Diharapkan dan Kejadian Nyaris Cedera di RSU Surya Husada. (Online) 2012. di http:// ui.ac.id,hal87-110,pdf. [diakses tanggal 20 Mei 2018].

15. Hafizurrachman, Trisnantoro, Laksono \& Bachtiar A. Beberapa Faktor yang Mempengaruhi Kinerja Perawat dalam Menjalankan Kebijakan di Rumah Sakit Umum Daerah. (Online) 2011. di http://indonesia.digitaljournals.org/index.php/idnmed/article/ viewFile/1075/1066. [diakses tanggal $20 \mathrm{Mei}$ 2018].

16. Iswari, Y.. Pengaruh Pendokumentasian Keperawatan dengan Metode Electronic Health Record (EHR). Artikel Penelitian Uni- 
versitas Indonesia. Jakarta. (Online) 2010. di http://pkko.fik.ui.ac.id/files/Tugas\%20UTS\% 20SIM_\%20Yeni_\%20Kep.\%20Anak.pdf. [diakses tanggal 20 Mei 2018].

17. Ulum, M.M. \& Wulandari R.D. Faktor yang Mempengaruhi Keparuhan Pendokumentasian Asuhan Keperawatan Berdasarkan Teori Milgram. Jurnal Administrasi Kesehatan Indonesia. 2013;1(3):252-262

18. Harmiady, R. Faktor-Faktor yang Berhubungan dengan Pelaksanaan Prinsip 6 Benar dalam Pemberian Obat oleh Perawat Pelaksana di Ruang Interna dan Bedah Rumah Sakit Haji Makassar. Makasar. Jurnal Ilmiah Kesehatan Diagnosis. 2014;5(4). ISSN : 2302-1721.

19. Hendroyogi, S.R. dan Harsono, M. Keterkaitan antara Persepsi Pentingnya Akreditasi Rumah Sakit Dengan Partisipasi, Komitmen, Kepuasan Kerja, dan Kinerja Karyawan. Jur- nal Ekonomi Manajemen Sumber Daya. 2016; 18(2):122-37.

20. Yildiz, A. and Kaya, S., Perceptions of Nurses on The Impact of Accreditation on Quality of Care : A Survey In a Hospital In Turkey. Clinical Governance: An International Journal. 2014;19(2):69-82.

21. Manzo, B.F., Ribeiro, H.C.T.C., Brito, M.J.M., Alves, M., Nursing in the Hospital Accreditation Process: Practice and Implications in the Work Quotidian. Rev. Latino-Am. Enfermagem. 2012;20(1):151-158.

22. Mangkuprawiro, S. Manajemen Sumber Daya Manusia Strategik. Cetakan Ketiga. Jakarta: Ghalia Indonesia. 2014.

23. Kuntarti, Tingkat Penerapan Prinsip Enam Tepat dalam Pemberian Obat oleh Perawat di Ruang Rawat Inap. Jurnal Keperawatan Indonesia. 2005;9(1):19-25 